\title{
Implementasi Holt-Winters Exponential Smoothing untuk Peramalan Harga Bahan Pangan di Kabupaten Pamekasan
}

\author{
Nindian Puspa Dewi ${ }^{1}$, Indah Listiowarni ${ }^{2}$ \\ 1,2Program Studi Informatika Fakultas Teknik Universitas Madura \\ ${ }^{1,2} \mathrm{Jl}$. Raya Panglegur KM.3,5 Pamekasan Madura \\ e-mail: 'nindianpd@unira.ac.id, ${ }^{2}$ indah@unira.ac.id
}

\begin{abstract}
Abstrak
Naik turunnya harga bahan pangan bisa menjadi penentu bagi setiap orang dalam menentukan makanan yang akan dikonsumsi, menyesuaikan dengan keadaan finansial mereka. Penelitian ini bertujuan untuk melakukan peramalan harga bahan pangan di masa mendatang dengan menggunakan data harga bahan pangan di masa sebelumnya. Dengan adanya peramalan harga, diharapkan dapat bermanfaat untuk membuat perencanaan pembelanjaan seperti perencanaan belanja bulanan dan penentuan harga jual makanan. Metode peramalan yang digunakan adalah Metode Holt-Winters Exponential Smoothing. Metode ini merupakan metode peramalan yang selain memperhatikan faktor trend juga melihat faktor musim. Penelitian ini hanya menggunakan harga bahan pangan di Kabupaten Pamekasan untuk periode 2012-2019. Hasil penelitian menunjukkan bahwa peramalan dengan menggunakan Metode Holt-Winters Exponential Smoothing menghasilkan nilai akurasi yang cukup baik dengan rata-rata nilai MAPE 1.2\% untuk Model Multiplikatif dan 1.02\% untuk Model Aditif. Hal ini menunjukkan bahwa Model Aditif lebih baik daripada Model Multiplikatif karena memiliki nilai MAPE yang lebih kecil.
\end{abstract}

Kata kunci: holt-winters, penghalusan eksponensial, peramalan, harga, bahan pangan

The fluctuation of food prices can be a determinant for everyone to choose what food they will consume, according to their financial condition. This study aims to forecast food prices in the future by using data on food prices in the past. With price forecasting, it can be useful for planning expenditures such as monthly shopping planning and determining the selling price of food. The method used in this research is the Holt-Winters Exponential Smoothing Method, which in addition to paying attention to trend factors, also observes season factors (seasonal). This study only uses food prices in Pamekasan Regency for the period 2012-2019. The results show that forecasting using the Holt-Winters Exponential Smoothing Method has a good accuracy value with an average MAPE value of 1.2\% for the Multiplicative Model and $1.02 \%$ for the Additive Model. This result shows that Additive Model is better than Multiplicative Model.

Keywords: holt-winters, exponential smoothing, forecasting, price, food.

\section{Pendahuluan}

Makanan adalah salah satu kebutuhan primer setiap manusia. Setiap hari manusia selalu berusaha untuk bisa memenuhi kebutuhan mereka terhadap makanan. Makanan diperoleh dengan cara membeli bahan-bahan pangan untuk kemudian diolah atau dapat juga dengan langsung membeli makanan yang sudah siap untuk dikonsumsi. Karena itulah, harga bahan pangan sangat berpengaruh dalam kehidupan manusia.

Perubahan harga bahan pangan biasanya mengalami perubahan sesuai dengan faktorfaktor yang mempengaruhinya, seperti musim, cuaca, dan kebutuhan manusia akan bahan pangan itu sendiri [1]. Dengan mengetahui perkembangan harga bahan pangan dan prediksi 
harga setiap bahan pangan, baik harga bahan pangan pokok maupun harga bahan pangan pendamping, kita dapat melakukan tindakan preventif untuk menekan lonjakan harga bahan pangan dikemudian hari. Selain itu, pengelolaan keuangan juga dapat direncanakan dengan lebih baik dan juga dapat melakukan perencanaan-perencanaan lainnya seperti menyimpan bahan pangan saat harganya sedang mengalami penurunan dan menggunakannya saat mengalami kenaikan harga. Contoh perubahan harga bahan pangan karena disebabkan oleh musim tertentu seperti pada saat musim penghujan, bahan pangan pendamping seperti cabe dan buah-buahan tertentu mengalami penurunan harga, karena pada musim penghujan buah-buahan cenderung mudah busuk dan hambar, atau pada masa Lebaran Idul Adha, biasanya banyak orang yang membagikan daging qurban, sehingga jumlah permintaan (pembelian) daging akan berkurang dan berpengaruh pada harga daging kambing dan sapi menjadi cenderung lebih murah. Sebaliknya menjelang Lebaran Idul Fitri, kebutuhan akan bahan pangan semakin meningkat sehingga harga bahan pangan cenderung mengalami kenaikan harga.

Hal utama yang melatarbelakangi penelitian ini adalah perubahan dan ketidakstabilan harga yang dipengaruhi oleh musim dan cuaca yang telah disebutkan sebelumnya. Dimana pada musim tertentu harga bahan pangan, bisa naik drastis atau cenderung murah. Karena itulah dirasa cukup bermanfaat jika bisa mengetahui atau meramalkan perkiraan harga bahan pangan di masa mendatang. Salah satu manfaatnya adalah dapat membantu kita dalam melakukan pengelolaan uang belanja bulanan, membantu dalam perencanaan pembelian bahan pangan di masa yang akan datang mendatang, seperti pengusaha catering yang sering kali menerima pemesanan makanan dalam jumlah besar untuk acara yang akan dilakukan di masa mendatang. Dengan mengetahui perkiraan harga bahan makanan, maka pengusaha katering dapat menentukan harga makanan yang akan dikenakan kepada pemesan sesuai dengan waktu pesanan akan diambil nantinya. Penentuan harga yang tepat dapat menghindari kerugian jika pada waktu mendatang harga bahan makanan mengalami kenaikan.

Peramalan atau yang biasa disebut dengan istilah forecasting adalah bagian dari sistem pendukung keputusan yang memberikan dugaan atau perkiraan pada hal-hal yang belum terjadi atau akan terjadi di masa mendatang dengan menggunakan sejumlah data yang ada sebelumnya [2]. Penelitian tentang peramalan telah banyak dilakukan seperti penggunaan Metode Monte Carlo untuk meramalkan ketersediaan Tery Crispy [3], implementasi Metode Holt-Winters dan Metode Simplex untuk menentukan stok Batik Madura [4], dan prediksi jumlah mahasiswa baru dengan menerapkan Metode Triple Exponential Smoothing [5]. Sedangkan beberapa penelitian tentang peramalan harga antara lain yaitu, penggunaan Metode Least Square untuk melakukan peramalan harga bahan-bahan proyek [6], perbandingan Metode ARIMA pada Amazon Forecast dan Sagemaker untuk memprediksi harga beras [7], Peramalan Indeks Harga Konsumen Kelompok Transportasi dengan menggunakan Holt's dan Winter's Exponential Smoothing [8], implementasi Model Variasi Kalender Regarima dengan Moving Holiday Effect untuk memprediksi harga Cabai Merah [9], dan peramalan harga cabai dengan Pemodelan Time Series ARIMA [10].

Metode yang digunakan dalam penelitian ini adalah Metode Holt-Winters Exponential Smoothing, yang merupakan metode peramalan yang tidak hanya melihat dari faktor trend tetapi juga melihat faktor musim (seasonal) [11]. Selain itu metode ini merupakan metode analisis time series [12] sehingga tepat untuk memprediksi harga bahan pangan. Hal ini sesuai dengan sifat perubahan harga bahan pangan yang selain biasanya mengalami kenaikan dari waktu ke waktu, juga sering dipengaruhi oleh musim (seasonal) seperti cuaca dan perayaan hari besar tiap tahunnya. Penelitian [13][14][15] juga menunjukkan bahwa Metode Exponential Smoothing memiliki nilai akurasi yang lebih tinggi daripada metode analisis time series lainnya. Karena harga bahan pangan di setiap daerah berbeda, maka dalam penelitian ini hanya berkonsentrasi pada sisi pemanfaatan dari Metode Holt-Winters Exponential Smoothing untuk mengetahui peramalan harga bahan pangan pokok dan pendamping di Kabupaten Pamekasan.

Peramalan dengan menggunakan Holt-Winters Exponential Smoothing memiliki dua model yaitu Model Multiplikatif dan Model Aditif. Tujuan penelitian ini adalah membandingkan performa kedua model tersebut. Jika nilai akurasi cukup baik, maka model 
yang terbaik dapat diterapakan pada penelitian selanjutnya, salah satunya untuk menentukan harga jual makanan berdasarkan peramalan harga bahan baku untuk periode yang akan datang.

\section{Metode Penelitian}

Untuk melakukan penelitian tentang peramalan harga bahan pangan, perlu dilakukan beberapa langkah penting yaitu pengumpulan data, melakukan proses inisialisasi atau penentuan nilai awal peramalan dan melakukan peramalan harga bahan pangan yang dalam penelitian ini menggunakan Metode Holt-Winters Exponential Smoothing. Metode ini merupakan salah satu metode time series yang selain memperhatikan faktor trend juga memperhatikan faktor musim (seasonal). Secara umum, tahapan dari metode ini ditunjukkan pada Gambar 1[1].

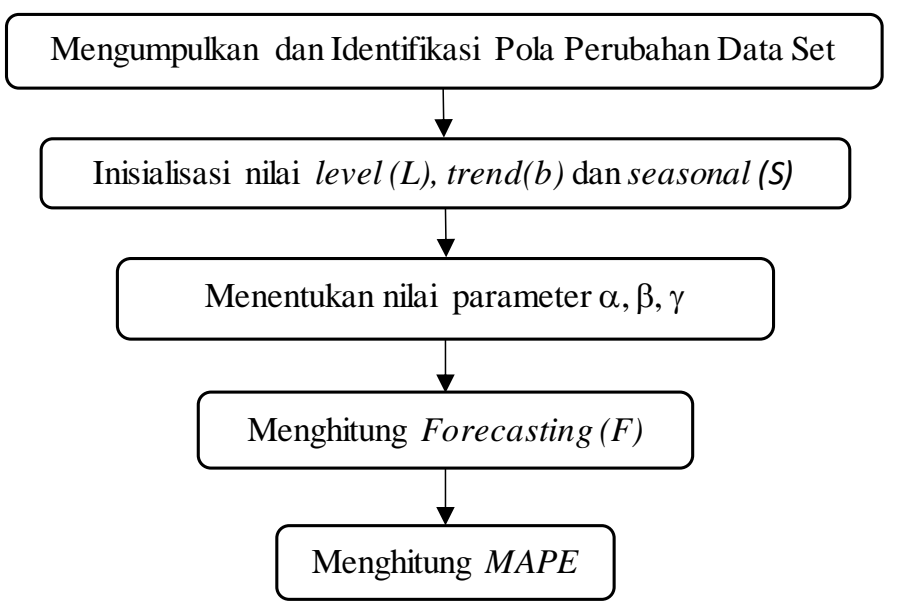

Gambar 1. Tahapan Metode Holt-Winters Exponential Smoothing

Langkah pertama untuk melakukan peramalan dengan menggunakan Metode HoltWinters Exponential Smoothing adalah mengumpulkan data set yaitu data harga bahan pangan. Setelah data terkumpul, maka langkah selanjutnya yaitu menentukan nilai awal (inisialisasi) level, trend dan seasonal. Setelah nilai awal dari ketiga variabel tersebut yaitu level, trend dan seasonal didapatkan, selanjutnya dapat dilakukan peramalan (forecasting) pada data set. Peramalan sendiri dapat dilakukan jika nilai parameter $\alpha, \beta$ dan $\gamma$. Lakukan beberapa kali perubahan nilai parameter ini untuk mendapatkan nilai peramalan terbaik. Penentuan tingkat kebaikan metode dapat dihitung dengan menggunakan (Mean Absolute Persen) [1].

\subsection{Pengumpulan Data}

Data harga bahan pangan di beberapa tahun lalu merupakan hal pertama yang harus dimiliki sebelum melakukan peramalan data. Karena itulah perlu dilakukan pengumpulan data sebelum melakukan langkah selanjutnya yaitu dengan melakukan kunjungan ke Dinas Ketahanan Pangan dan Peternakan Kabupaten Pamekasan serta melakukan observasi secara langsung ke sejumlah toko dan pasar. Penelitian ini menggunakan data harga sejumlah bahan pangan yang diperoleh dari Dinas Ketahanan Pangan dan Peternakan Kabupaten Pamekasan. Adapun data yang akan digunakan adalah data harga beberapa bahan pangan dimulai dari Bulan Januari 2012 sampai dengan Bulan Desember 2019. Untuk data harga pada Tahun 2020, data diperoleh dengan melakukan survei langsung ke Pasar terbesar di Pamekasan yaitu Pasar Kolpajung dan Pasar 17 Agustus Pamekasan. Data pada Tahun 2020 yang dimiliki hanya sampai Bulan Agustus sesuai dengan waktu terakhir pengumpulan data.

\subsection{Inisialisasi Nilai Level, Trend dan Seasonal}

Dalam Holt-Winters Exponential Smoothing, ada tiga variabel penting yaitu level, trend dan seasonal yang digunakan dalam proses perhitungan. Untuk menentukan nilai awal dalam Metode Holt-Winters Exponential Smoothing diperlukan satu deret data dalam satu periode musiman (s). Dalam penelitian ini akan digunakan periode musiman $\mathrm{s}=12$ yang merupakan jumlah bulan dalam satu periode musim. Adapun langkah-langkahnya sebagai berikut [16][17]: 
Langkah 1. Inisialisasi nilai awal level $\boldsymbol{L}_{s}$ dengan menggunakan persamaan (1). Menentukan nilai awal level $L_{s}$ dengan menggunakan persamaan (1).

$L_{s}=\left(Y_{1}+Y_{2}+\cdots+Y_{s}\right) / s$

dimana,

$L_{s}=$ Inisialisasi Level

$Y_{s}=$ Harga Bahan Pokok ke-s

$s \quad=$ Periode Musiman $(\mathrm{s}=12)$

Langkah 2. Menentukan nilai awal trend $b_{s}$ dengan menggunakan persamaan (2).

$b_{s}=\left(Y_{s}+1-Y_{1}\right) / s$

dimana,

$b_{s}=$ Inisialisasi trend

$Y_{s+1}=$ Harga Bahan Pokok ke-(s+1)

$s \quad=$ Panjang Musiman $(\mathrm{s}=12)$

Langkah 3. Menentukkan nilai awal untuk indeks musiman (seasonal) denga menggunakan persamaan (3) untuk multikatif dan persamaan (4) untuk aditif.

$S_{p}=Y_{p} / L_{s}$

$S_{p}=Y_{p}-L_{s}$

dimana,

$S_{p}=$ Inisialisasi seasonal

$Y_{p}=$ Harga Bahan Pokok ke- $p$

$p=$ Periode Musiman di Tahun Pertama $(p=1,2,3 \ldots 12)$

\subsection{Forecasting}

Setelah menentukan nilai awal dari level, trend dan seasonal, maka langkah selanjutnya adalah melakukan peramalan harga bahan pangan. Sebelumnya perlu ditentukan nilai parameter $\alpha, \beta$ dan $\gamma . \alpha$ merupakan konstanta pembobot pemulusan eksponential $(0<\alpha<1), \beta$ adalah konstanta pembobot pemulusan unsur kecenderungan $(0<\beta<1)$ dan $\gamma$ adalah konstanta pembobot pemulusan musiman $(0<\gamma<1)$ [4].

Peramalan dengan menggunakan Holt-Winters Exponential Smoothing memiliki dua model yaitu Model Multiplikatif dan Model Aditif. Penelitian ini menggunakan dua model tersebut dengan langkah proses dan persamaan sebagai berikut [18][19]:

Langkah 1. Menghitung Pemulusan Eksponensial (Level) dengan menggunakan persamaan (5) untuk model multiplikatif dan persamaan (6) untuk model aditif.

$L_{t}=\alpha \frac{Y_{t}}{S_{t-s}}+(1-\alpha)\left(L_{t-1}+b_{t-1}\right)$

$L_{t}=\alpha\left(Y_{t}-S_{t-s}\right)+(1-\alpha)\left(L_{t-1}+b_{t-1}\right)$

dimana,

$L_{t} \quad=$ Level pada tahun ke- $t$

$L_{t-1}=$ Level pada tahun ke- $t-1$

$b_{t-1}=$ Trend pada tahun ke- $t-1$

$Y_{t}=$ Harga Bahan Pokok ke- $t$

$\alpha=$ Konstanta pembobot level $(0<\alpha<1)$

$S_{t} \quad=$ Seasonal pada tahun ke- $t$

$s \quad=$ Panjang Musiman $(s=12)$

Langkah 2. Menghitung pemulusan unsur kecenderungan (trend) dengan menggunakan persamaan (7) baik untuk model multiplikatif maupun model aditif.

$b_{t}=\beta\left(L_{t}-L_{t-1}\right)+(1-\beta) b_{t-1}\left(L_{t-1}+b_{t-1}\right) \quad$ (7) 
dimana

$b_{t}=$ Trend pada tahun ke- $t$

$L_{t} \quad=$ Level pada tahun ke- $t$

$L_{t-1}=$ Level pada tahun ke- $t-1$

$b_{t-1}=$ Trend pada tahun ke- $t-1$

$\beta=$ Konstanta pembobot trend $(0<\beta<1)$

$t \quad=$ Periode Musiman

Langkah 3. Menghitung Pemulusan Musiman dengan menggunakan persamaan (8) untuk model multiplikatif dan persamaan (9) untuk model aditif.

$S_{t}=\gamma \frac{Y_{t}}{L_{t}}+(1-\gamma) S_{t-s}$

$S_{t}=\gamma\left(Y_{t}-L_{t}\right)+(1-\gamma) S_{t-s}$

dimana,

$S_{t}=$ Seasonal pada tahun ke- $t$

$Y_{t}=$ Harga Bahan Pokok ke- $t$

$L_{t}=$ Pemulusan Eksponensial pada tahun ke- $t$

$\gamma=$ Konstanta pembobot pemulusan musiman $(0<\gamma<1)$

$S_{t-s}=$ Pemulusan Faktor Musiman

$t=$ Periode Musiman

$s \quad=$ Panjang Musiman $(s=12)$

Langkah 4. Selanjutnya peramalan (forecasting) harga bahan pangan didapatkan dengan menggunakan persamaan (10) untuk model multiplikatif dan persamaan (11) untuk model aditif.

$F_{t+m}=\left(L_{t}+b_{t} m\right) S_{t-s+m}$

$F_{t+m}=L_{t}+b_{t} m+S_{t-s+m}$

dimana,

$F_{t+m}=$ Hasil Peramalan ke- $t+m$

$L_{t}=$ Pemulusan Eksponensial pada tahun ke- $t$

$S_{t-s}=$ Pemulusan Faktor Musiman

$t=$ Periode Musiman

$s \quad=$ Panjang Musiman $(s=12)$

$m$ = Periode waktu yang akan diramalkan

\subsection{Perhitungan MAPE}

Untuk mengetahui model mana yang paling akurat antara model multiplikatif dan aditif perlu dilakukan perhitungan nilai kebaikan model yang pada penelitian ini akan digunakan perhitungn MAPE (Mean Absolute Persen) [4]. Hasil dari MAPE berupa persentase dengan menggunakan persamaan (12) berikut ini.

$M A P E=\frac{1}{n} \sum_{t=1}^{n}\left|\frac{Y_{t}-\hat{Y}_{t}}{Y_{t}}\right| x 100 \%$

dimana,

$\mathrm{n} \quad=$ Jumlah Data yang Diamati

$Y_{t}=$ Harga Bahan Pokok ke- $t$

$\hat{Y}_{t}=$ Hasil Peramalan ke- $t$

$t=$ Periode Musiman di Tahun Pertama $(t=1,2,3 \ldots \mathrm{n})$

\section{Hasil dan Pembahasan}

Data harga bahan pangan yang dijadikan dataset dalam penelitian ini adalah data harga daging ayam broiler, kentang, telur, bawang merah, gula dan beras di Kabupaten Pamekasan. Total jumlah data harga adalah 108 data untuk masing-masing bahan pangan yang akan digunakan dimulai dari Bulan Januari Tahun 2012 sampai dengan Bulan Desember Tahun 2019. 
Pada bagian ini data yang ditunjukkan hanya hasil pengolahan data harga untuk daging ayam broiler, kentang dan telur.

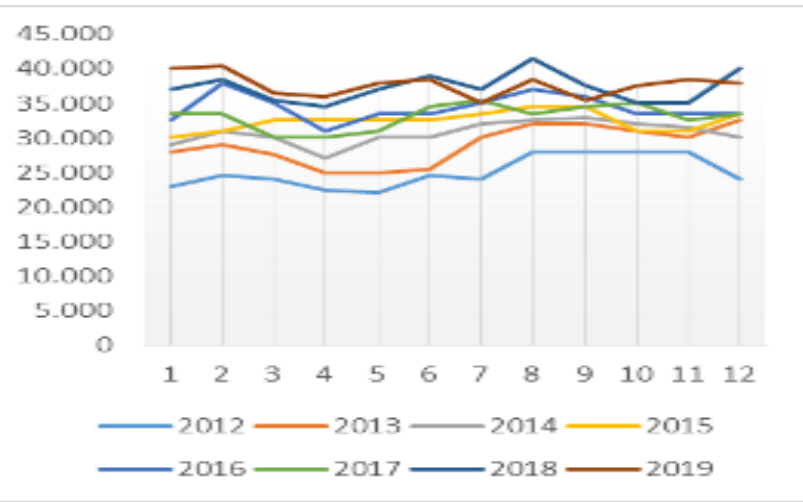

Gambar 2. Grafik Perubahan Harga Daging Ayam

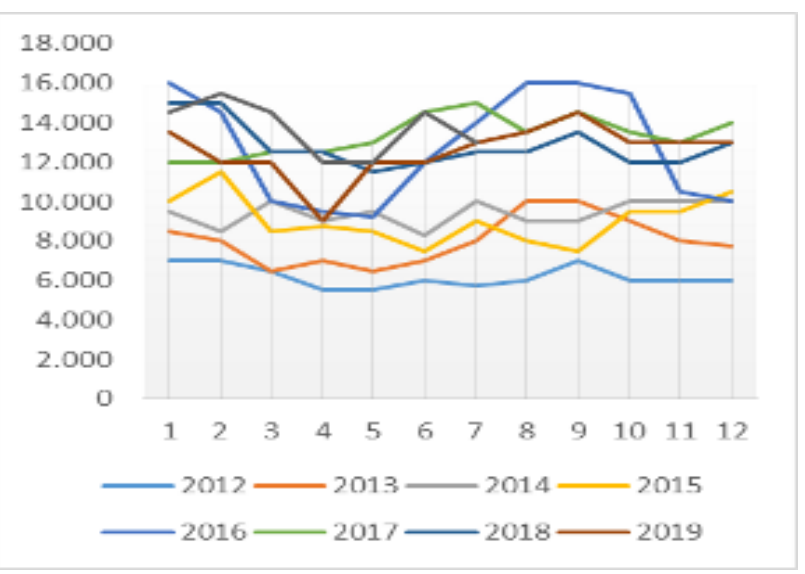

Gambar 3. Grafik Perubahan Harga Kentang

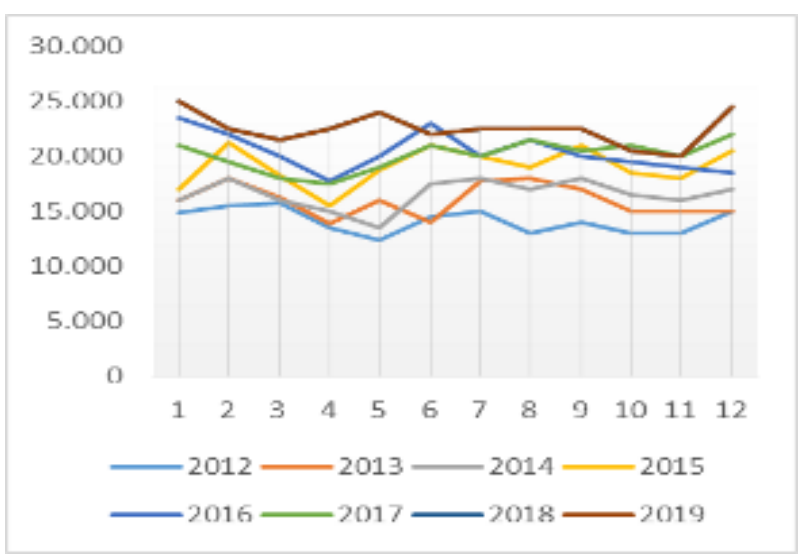

Gambar 4. Grafik Perubahan Harga Telur

Gambar 2 sampai dengan Gambar 4 menunjukkan grafik perubahan harga untuk data harga daging ayam broiler, kentang dan telur. Grafik memperlihatkan bahwa selalu mengalami kenaikan harga dari tahun ke tahun, namun di setiap tahunnya terjadi perubahan atau naik turun harga. Seperti harga daging ayam broiler yang mengalami kenaikan saat menjelang Idul Fitri hingga Idul Adha.

Setelah data terkumpul, langkah selanjutnya adalah proses inisialisasi atau pemberian nilai awal untuk level, trend dan seasonal yang digunakan dalam proses perhitungan selanjutnya. Tabel 1 sampai dengan Tabel 3 menunjukkan nilai awal level, trend dan seasonal dari bawang merah,daging ayam broiler dan telur. 
Tabel 1. Inisialisasi Data untuk Data Harga Daging Ayam Broiler

\begin{tabular}{|c|c|c|c|c|c|}
\hline Tahun & $\mathrm{t}$ & $\operatorname{Harga}(\mathrm{Y})$ & $\overline{\text { Level (L) }}$ & Trend (b) & Seasonal (S) \\
\hline \multicolumn{6}{|c|}{ Multiplikatif } \\
\hline \multirow[t]{4}{*}{2012} & 1 & 9.500 & & & 0,926 \\
\hline & 2 & 9.000 & & & 0,878 \\
\hline & 11 & 8.000 & & & 0,780 \\
\hline & 12 & 13.500 & 10.250 & 333 & 1,317 \\
\hline \multicolumn{6}{|l|}{ Aditif } \\
\hline \multirow[t]{4}{*}{2012} & 1 & & & & -750 \\
\hline & 2 & & & & -1.250 \\
\hline & 11 & 8.000 & & & -2.250 \\
\hline & 12 & 13.500 & 10.250 & 333 & 3.250 \\
\hline
\end{tabular}

Tabel 2. Inisialisasi. Inisialisasi Data untuk Data Harga Kentang

\begin{tabular}{|c|c|c|c|c|c|c|}
\hline \multirow{2}{*}{\multicolumn{7}{|c|}{$\begin{array}{cr}\text { Tahun } & \mathrm{t} \\
\text { Multiplikatif }\end{array}$}} \\
\hline & & & & & & \\
\hline \multirow[t]{4}{*}{2012} & 1 & 7.000 & & & & 1,131 \\
\hline & 2 & 7.000 & & & & 1,131 \\
\hline & 11 & 6.000 & & & & 0,969 \\
\hline & 12 & 6.000 & $6.187,5$ & -83 & & 0,969 \\
\hline \multicolumn{7}{|l|}{ Aditif } \\
\hline \multirow{4}{*}{2012} & 1 & 7.000 & & & & 813 \\
\hline & 2 & 7.000 & & & & 813 \\
\hline & 11 & 6.000 & & & & -188 \\
\hline & 12 & 6.000 & $6.187,5$ & -83 & -188 & \\
\hline
\end{tabular}

Tabel 3. Inisialisasi Data untuk Data Harga Telur

\begin{tabular}{|c|c|c|c|c|c|}
\hline Tahun & $\mathrm{t}$ & Harga (Y) & Level (L) & Trend (b) & Seasonal $(\mathrm{S})$ \\
\hline \multicolumn{6}{|c|}{ Multiplikatif } \\
\hline \multirow[t]{4}{*}{2012} & 1 & 14.850 & & & 1,051 \\
\hline & 2 & 15.500 & & & 1,097 \\
\hline & 11 & 13.000 & & & 0,920 \\
\hline & 12 & 15.000 & 14.120 & 13 & 1,062 \\
\hline \multicolumn{6}{|l|}{ Aditif } \\
\hline \multirow[t]{4}{*}{2012} & 1 & 14.850 & & & 729 \\
\hline & 2 & 15.500 & & & 1.379 \\
\hline & 11 & 13.000 & & & -1.121 \\
\hline & 12 & 15.000 & 14.120 & 13 & 879 \\
\hline
\end{tabular}

Langkah selanjutnya adalah melakukan proses peramalan (forecasting) harga bahan pangan. Peramalan pada dataset dilakukan dimulai dari data tahun 2013 (periode musim kedua) sampai dengan tahun 2019. Tabel 4 sampai Tabel 6 menunjukkan hasil peramalan dengan menggunakan persamaan (5) sampai dengan persamaan (11).

Nilai $\alpha, \beta$ dan $\gamma$ yang digunakan ada diantara 0 dan 1 . Adapun untuk percobaan peramalan harga daging ayam broiler dengan model multiplikatif menggunakan nilai $\alpha=0.9, \beta=0.1$ dan $\gamma=0.8$ dan untuk model aditif menggunakan nilai $\alpha=0.9, \beta=0.1$ dan $\gamma=0.9$. Pemilihan nilai ini karena setelah dilakukan beberapa kali percobaan menghasilkan nilai dengan error terkecil. 
Tabel 4. Permalan Data Harga Daging Ayam Broiler

\begin{tabular}{ccrrccc}
\hline Tahun & $\mathrm{t}$ & Harga (Y) & Level (L) & Trend (b) & Seasonal (S) & Forecasting (F) \\
\hline \multicolumn{2}{c}{ Multiplikatif } & & & & & \\
\hline 2013 & 1 & 28.000 & $29.949,5$ & 565,9 & 0,932 & 28.027 \\
& 2 & 29.000 & $29.728,6$ & 487,2 & 0,976 & 29.562 \\
\hline & $\ldots$ & $\ldots$ & $\ldots$ & $\ldots$ & $\ldots$ & $\ldots$ \\
2019 & $\ldots$ & $\ldots$ & $\ldots$ & $\ldots$ & $\ldots$ \\
& 11 & 38.500 & $34.714,7$ & $-228,0$ & 1,108 & 38.131 \\
\hline Aditif & & & & & & \\
\hline 2013 & 1 & 28.000 & $36.547,1$ & $-22,0$ & 1,038 & 37.741 \\
\hline & 2 & 29.000 & $29.550,0$ & 525,9 & -1.599 & 28.034 \\
2019 & $\ldots$ & $\ldots$ & $\ldots$ & $\ldots$ & -590 & 29.531 \\
& 11 & 38.500 & $35.898,0$ & $-91,3$ & 2.592 & 38.306 \\
& 12 & 38.000 & $36.506,5$ & $-21,3$ & 1.486 & 37.901 \\
\hline
\end{tabular}

Tabel 5. Peramalan Harga Kentang

\begin{tabular}{ccccccc}
\hline Tahun & $\mathrm{t}$ & Harga $(\mathrm{Y})$ & Level $(\mathrm{L})$ & Trend $(\mathrm{b})$ & Seasonal $(\mathrm{S})$ & Forecasting $(\mathrm{F})$ \\
\hline \multicolumn{2}{c}{ Multiplikatif } & & & & & \\
\hline 2013 & 1 & 8.500 & 7.372 & 44 & 1,133 & 8.390 \\
& 2 & 8.000 & 7.106 & 13 & 1,131 & 8.053 \\
& $\ldots$ & $\ldots$ & $\ldots$ & $\ldots$ & $\ldots$ & $\ldots$ \\
2019 & 11 & 13.000 & 13.471 & 72 & 0,964 & 13.057 \\
& 12 & 13.000 & 13.412 & 59 & 0,970 & 13.071 \\
Aditif & & & & & & \\
\hline 2013 & 1 & 8.500 & 7.529 & 59,2 & 828 & 8.401 \\
& 2 & 8.000 & 7.228 & 23,2 & 808 & 8.063 \\
2019 & 11 & 13.000 & 13.256 & 56,0 & -254 & 13.059 \\
& 12 & 13.000 & 13.189 & 43,6 & -176 & 13.057 \\
\hline
\end{tabular}

Tabel 6. Peramalan Harga Telur

\begin{tabular}{ccccccc}
\hline Tahun & $\mathrm{t}$ & Harga $(\mathrm{Y})$ & \multicolumn{6}{c}{ Level (L) } & Trend (b) & Seasonal (S) & Forecasting (F) \\
\hline & \multicolumn{6}{c}{ Multiplikatif } \\
\hline 2013 & 1 & 16.000 & 15.106 & 109,8 & 1,052 & 16.002 \\
& 2 & 18.000 & 16.280 & 216,2 & 1,098 & 18.108 \\
& 3 & 16.250 & 14.762 & 42,8 & 1,114 & 16.513 \\
& $\ldots$. & $\ldots$ & $\ldots$ & $\ldots$ & $\ldots$ & $\ldots$ \\
2019 & 11 & 20.000 & 21.824 & $-64,3$ & 0,919 & 19.994 \\
& 12 & 24.500 & 23.039 & 63,6 & 1,058 & 24.417 \\
& & \multicolumn{7}{c}{ Aditif } & & \\
\hline 2013 & 1 & 16.000 & 15.157 & 114,9 & 741 & 16.001 \\
& 2 & 18.000 & 16.486 & 236,3 & 1.393 & 18.101 \\
& $\ldots$. & $\ldots$ & $\ldots$ & $\ldots$ & $\ldots$ & $\ldots$ \\
2019 & 11 & 20.000 & 21.212 & $-107,0$ & -1.162 & 19.949 \\
& 12 & 24.500 & 23.406 & 123,1 & 863 & 24.367 \\
\hline
\end{tabular}

Tabel 5 menunjukkan data hasil peramalan untuk harga kentang dengan menggunakan nilai $\alpha=0.9, \beta=0.1$ dan $\gamma=0.1$ baik untuk model multiplikatif maupun untuk model aditif. Selanjutnya untuk proses peramalan harga telur digunakan nilai $\alpha=0.9, \beta=0.1$ dan $\gamma=0.1$ baik untuk model multiplikatif maupun untuk model aditif. Hasil peramalan harga telur ditunjukkan pada Tabel 6.

Untuk melakukan peramalan di Tahun 2020, digunakan data level, trend dan seasonal pada bulan desember 2019. Data harga pada Tahun 2020 dari Bulan Januari sampai dengan Bulan Agustus merupakan data hasil observasi yang diperoleh dari rata-rata harga pasar yang digunakan sebagai pembanding hasil peramalan. 
Tabel 7 menunjukkan hasil peramalan harga daging ayam di Tahun 2020. Hasil peramalan menunjukkan pada awal tahun 2020 masih menghasilkan nilai error yang tidak terlalu tinggi. Namun memasuki bulan ke-3 sampai bulan ke-7 mengalami kenaikan yang cukup signifikan. Hal ini karena pada saat itu kondisi perekonomian Indonesia sangat dipengaruhi oleh masa pandemi Covid-19 yang menyebabkan harga pakan ternak yang semakin mahal. Naiknya harga pakan ini diiringi dengan naiknya harga daging ayam. Dan ini berlanjut dengan berkurangnya minat konsumen, sehingga banyak pengusaha ayam beralih mencoba usaha yang lain. Peralihan usaha inilah yang menyebabkan kurangnya pasokan daging ayam dari supplier dan akhirnya juga mengakibatkan harga daging ayam tetap tinggi.

\begin{tabular}{cccc} 
Tabel 7. Peramalan & \multicolumn{3}{c}{ Harga Daging Ayam Broiler Tahun 2020 } \\
\cline { 2 - 4 } Bulan & $\begin{array}{c}\text { Data } \\
\text { Observasi }\end{array}$ & $\begin{array}{c}\text { Model } \\
\text { Multiplikatif }\end{array}$ & $\begin{array}{c}\text { Model } \\
\text { Aditif }\end{array}$ \\
\hline Januari & 37.000 & 34.925 & 35.742 \\
Februari & 37.500 & 35.628 & 36.129 \\
Maret & 40.500 & 34.074 & 34.415 \\
April & 36.500 & 32.690 & 33.565 \\
Mei & 34.000 & 32.847 & 34.157 \\
Juni & 42.500 & 34.466 & 35.206 \\
Juli & 41.000 & 34.843 & 35.270 \\
Agustus & 36.500 & 38.839 & 38.327 \\
September & - & 39.476 & 38.286 \\
Oktober & - & 39.915 & 38.614 \\
November & - & 40.239 & 38.864 \\
Desember & - & 37.678 & 37.737 \\
\hline
\end{tabular}

Untuk grafik Pebandingan hasil peramalan dengan data harga daging ayam broiler yang sebenarnya dapat dilihat pada Gambar 5. Berbeda dengan Tabel 4, Gambar 5 menunjukkan Grafik yang memperlihatkan bahwa selisih hasil peramalan dengan data aktual pada Tahun 2020 cukup besar karena adanya fluktuasi harga sebagai akibat Covid-19.

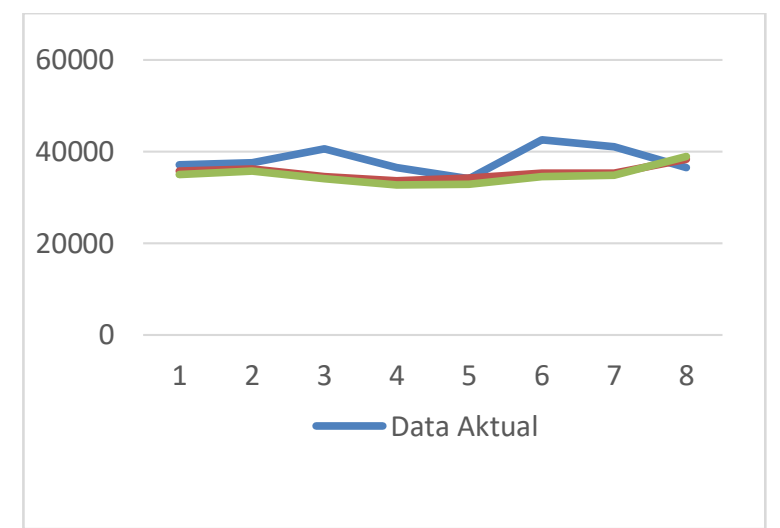

Gambar 5. Grafik Perbandingan Hasil Peramalan dengan Data Harga Daging Ayam Broiler

Tabel 8. Peramalan Harga Kentang Tahun 2020

\begin{tabular}{cccc}
\hline Bulan & $\begin{array}{c}\text { Data } \\
\text { Observasi }\end{array}$ & $\begin{array}{c}\text { Model } \\
\text { Multiplikatif }\end{array}$ & $\begin{array}{c}\text { Model } \\
\text { Aditif }\end{array}$ \\
\hline Januari & 14500 & 15.255 & 14.104 \\
Februari & 15500 & 15.266 & 14.060 \\
Maret & 14500 & 14.208 & 13.566 \\
April & 12000 & 12.217 & 12.699 \\
Mei & 12000 & 12.208 & 12.742 \\
Juni & 14500 & 13.287 & 13.258 \\
Juli & 13000 & 12.968 & 13.150 \\
Agustus & 14000 & 13.431 & 13.344
\end{tabular}




\begin{tabular}{cccc}
\hline Bulan & $\begin{array}{c}\text { Data } \\
\text { Observasi }\end{array}$ & $\begin{array}{c}\text { Model } \\
\text { Multiplikatif }\end{array}$ & $\begin{array}{c}\text { Model } \\
\text { Aditif }\end{array}$ \\
\hline September & - & 15.608 & 14.340 \\
Oktober & - & 13.679 & 13.467 \\
November & - & 13.559 & 13.415 \\
Desember & - & 13.701 & 13.536 \\
\hline
\end{tabular}

Tabel 8 berikut menunjukkan hasil peramalan harga kentang di Tahun 2020. Berbeda dengan daging ayam yang merupakan bahan pangan pokok, kentang merupakan bahan pangan pendamping, sehingga nilai error antara data di lapangan dan hasil peramalan cukup baik sekalipun dalam masa pandemi Covid-19. Karena itulah hasil peramalan yang diperoleh juga tidak memiliki rentangan yang cukup jauh seperti halnya pada daging ayam. Grafik Perbandingan hasil per amalan dengan data harga kentang yang sebenarnya dapat dilihat pada Gambar 6.

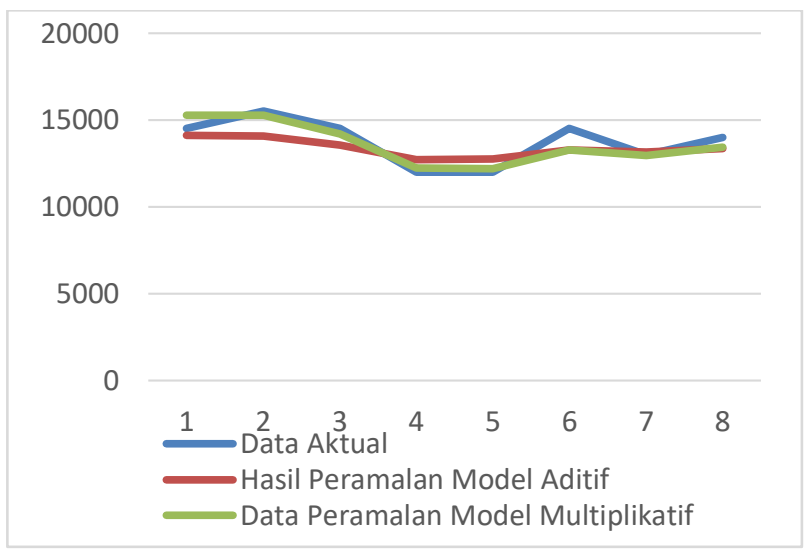

Gambar 6. Grafik Perbandingan Hasil Peramalan dengan Data Harga Kentang

Tabel 9. Peramalan Harga Telur Tahun 2020

\begin{tabular}{cccc}
\hline Bulan & $\begin{array}{c}\text { Data } \\
\text { Observasi }\end{array}$ & $\begin{array}{c}\text { Model } \\
\text { Multiplikatif }\end{array}$ & $\begin{array}{c}\text { Model } \\
\text { Aditif }\end{array}$ \\
\hline Januari & 25000 & 24.426 & 24.375 \\
Februari & 22500 & 25.362 & 24.981 \\
Maret & 25000 & 25.722 & 25.275 \\
April & 23500 & 22.371 & 23.335 \\
Mei & 22000 & 20.666 & 22.454 \\
Juni & 22500 & 23.841 & 24.431 \\
Juli & 25500 & 24.886 & 25.120 \\
Agustus & 25000 & 21.861 & 23.390 \\
September & - & 23.279 & 24.314 \\
Oktober & - & 21.771 & 23.473 \\
November & - & 21.807 & 23.599 \\
Desember & - & 25.172 & 25.747 \\
\hline
\end{tabular}

Tabel 9 menunjukkan hasil peramalan harga telur di Tahun 2020. Berbeda dengan daging ayam broiler yang mengalami kenaikan harga, harga telur ayam broiler justru cukup stabil. Hal ini karena kebutuhan masyarakat pamekasan terhadap telur tidak berkurang. Apalagi di masa pandemi Covid-19 ini, banyak yang lebih senang menyimpan makanan yang bisa disimpan untuk jangka waktu yang lebih lama, dimana telur adalah salah satunya. Karena itulah banyak peternak ayam di Pamekasan yang tetap bertahan menjadi pemasok telur. Sehingga sekalipun sempat terjadi perubahan harga namun tidak terlalu signifikan. Hal ini dapat dilihat dari hasil peramalan yang didapat tidak berbeda jauh dengan harga di lapangan.

Grafik Perbandingan hasil peramalan dengan data harga telur yang sebenarnya dapat dilihat pada Gambar 7. 


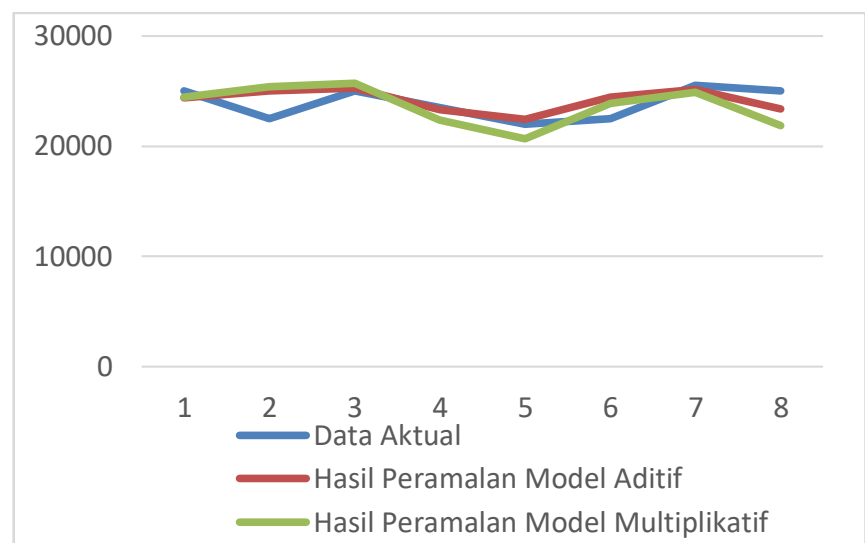

Gambar 7. Grafik Perbandingan Hasil Peramalan dengan Data Harga Telur

Jika dilihat dari ketiga grafik perbandingan antara data harga actual dan data hasil peramalan, semuanya menghasilkan grafik yang stasioner.

Model data dikatakan baik jika memiliki nilai MAPE di bawah 10\%. Tabel 10 menunjukkan perbandingan nilai MAPE antara Model Multiplikatif dan Model Aditif. Perbandingan ini menunjukkan bahwa Model Multiplikatif dan Model Aditif sama-sama memiliki akurasi yang baik karena memiliki nilai MAPE di bawah 10\%. Namun Model Aditif memiliki akurasi yang lebih baik daripada Model Multiplikatif.

Tabel 10. Perbandingan Nilai MAPE

\begin{tabular}{|c|c|c|c|c|}
\hline \multirow{2}{*}{ Bahan Pangan } & \multicolumn{2}{|c|}{ Model Multiplikatif } & \multicolumn{2}{|c|}{ Model Aditif } \\
\hline & Parameter & MAPE & Parameter & MAPE \\
\hline Daging Ayam Broiler & $\alpha=0.9, \beta=0.1, \gamma=0.1$ & $0,89 \%$ & $\alpha=0.9, \beta=0.1, \gamma=0.9$ & $0,75 \%$ \\
\hline Kentang & $\alpha=0.9, \beta=0.1, \gamma=0.1$ & $1,14 \%$ & $\alpha=0.9, \beta=0.1, \gamma=0.1$ & $1,08 \%$ \\
\hline Telur & $\alpha=0.9, \beta=0.1, \gamma=0.1$ & $0,87 \%$ & $\alpha=0.9, \beta=0.1, \gamma=0.1$ & $0,78 \%$ \\
\hline Bawang Merah & $\alpha=0.9, \beta=0.1, \gamma=0.9$ & $2,63 \%$ & $\alpha=0.9, \beta=0.1, \gamma=0.9$ & $2,23 \%$ \\
\hline Gula & $\alpha=0.9, \beta=0.1, \gamma=0.9$ & $0,98 \%$ & $\alpha=0.9, \beta=0.1, \gamma=0.9$ & $0,93 \%$ \\
\hline Beras & $\alpha=0.8, \beta=0.1, \gamma=0.1$ & $0,372 \%$ & $\alpha=0.8, \beta=0.1, \gamma=0.1$ & $0,370 \%$ \\
\hline
\end{tabular}

Hasil penelitian menunjukkan bahwa metode ini masih sama baiknya dengan penelitian sebelumnya yang melakukan peramalan harga dengan menggunakan Metode Arima [6] dan Holt's dan Winter's Exponential Smoothing [7], namun lebih baik dari pada penelitian [8] yang menggunakan Metode Least Square dan yang menggunakan Moving Holiday Effect [9].

\section{Kesimpulan}

Metode Holt-Winters Exponential Smoothing sangat baik jika digunakan untuk melakukan peramalan harga bahan pangan di Kabupaten Pamekasan. Hal ini sesuai dengan hasil peramalan pada sejumlah bahan pangan di Kabupaten Pamekasan, baik dengan Model Multiplikatif maupun Model Aditif menghasilkan nilai MAPE di bawah 10\%. Meskipun tidak berbeda terlalu jauh, model aditif memiliki akurasi yang lebih baik daripada model multikatif karena memiliki nilai MAPE yang lebih kecil.

Karena akurasi model aditif yang sangat baik dan lebih baik dari Model Multiplikatif, maka model ini dapat dimanfaatkan untuk penelitian selanjutnya yaitu untuk membuat rencana pengelolaan belanja bagi ibu rumah tangga maupun untuk menentukan harga jual makanan bagi pengusaha catering di masa mendatang khususnya di wilayah Kabupaten Pamekasan.

\section{Ucapan Terimakasih}

Terima kasih kepada Direktorat Riset dan Pengabdian kepada Masyarakat khususnya Direktorat Jenderal Penguatan Riset dan Pengembangan atas bantuan dana penelitian sehingga penelitian ini dapat dilaksanakan dengan baik. Terima kasih juga untuk semua pihak yang secara tidak langsung membantu pelaksanaan penelitian ini. 


\section{Daftar Pustaka}

[1] E. Sondakh, R. . Kaunang, and P. A. Pangemanan, "Faktor-Faktor Yang Mempengaruhi Pendapatan Pedagang Beras Dalam Menghadapi Fluktuasi Harga Di Kota Manado," Agri-Sosioekonomi, vol. 12, no. 1A, p. 103, 2016.

[2] D. C. Montgomery, C. L. Jennings, and M. Kulahci, Introduction to Time Series Analysis and Forecasting, no. 1. Canada: ohn Wiley \& Sons.Inc, 2003.

[3] E. Prasetyo, "Aplikasi Simulasi Persediaan Teri Crispy Prisma Menggunakan Metode Monte Carlo," J. Sist. dan Teknol. Inf. Indones., vol. 01, pp. 43-49, 2016.

[4] E. Prasetyowati and B. Said, "Penentuan Stok Batik Madura Berdasarkan Keterbatasan Produksi Menggunakan Holt-Winters Model Dan Simplex Method," Semin. Nas. Inov. dan Apl. Teknol. di Ind. 2019, pp. 7-14, 2019, doi: 2085-4218.

[5] F. Andrian, S. Martha, and S. Rahmayuda, "Sistem Peramalan Jumlah Mahasiswa Baru Menggunakan Metode Triple Exponential Smoothing," J. Komput. dan Apl., vol. 08, no. 01, pp. 112-121, 2020.

[6] N. P. Dewi and I. Listiowarni, "Peramalan Harga Bahan Proyek Menggunakan Metode Least Square (Studi Kasus : CV Rizky Mulya)," J. Teknol. Inform., vol. 2617, no. 1, pp. 27-33, 2019.

[7] R. Sistem, I. Mardianto, M. I. Gunawan, D. Sugiarto, and A. Rochman, "Perbandingan Peramalan Harga Beras Menggunakan Metode ARIMA pada Amazon Forecast dan Sagemaker,” J. Resti (Rekayasa Sist. dan Teknol. Informasi), vol. 1, no. 10, 2021.

[8] A. Fahlevi, F. A. Bachtiar, and B. D. Setiawan, "Perbandingan Holt' s dan Winter' s Exponential Smoothing untuk Peramalan Indeks Harga Konsumen Kelompok Transportasi , Komunikasi dan Jasa Keuangan,” J. Pengemb. Teknol. Inf. dan Ilmu Komput., vol. 2, no. 12, pp. 6136-6145, 2018,

[9] A. R. Nisa, Tarno, and A. Rusgiyono, "Peramalan Harga Cabai Merah Menggunakan Model Variasi Kalender Regarima dengan Moving Holiday Effect (Studi Kasus: Harga Cabai Merah Periode Januari 2012 Sampai Dengan Desember 2019 Di Provinsi Jawa Barat)," Junal Gaussian, vol. 9, pp. 170-181, 2020.

[10] F. N. Hadiansyah, "Prediksi Harga Cabai dengan Pemodelan Time Series ARIMA," Ind. J. Comput., vol. 2, no. 2010, pp. 71-78, 2017, doi: 10.21108/indojc.2017.21.144.

[11] S. N. Hamidah, N. Salam, D. S. Susanti, J. A. Yani, K. Kampus, and U. Banjarbaru, "Teknik Peramalan Menggunakan Metode Pemulusan Eksponensial Holt-Winters," J. Mat. Murni dan Terap. “epsilon,” vol. 07, no. 02, pp. 26-33,2017

[12] S. Lima, A. M. Gonçalves, and M. Costa, "Time series forecasting using Holt-Winters exponential smoothing: An application to economic data," AIP Conf. Proc., vol. 2186, no. $1,2019$.

[13] M. A. Maricar, "Analisa Perbandingan Nilai Akurasi Moving Average dan Exponential Smoothing untuk Sistem Peramalan Pendapatan pada Perusahaan XYZ," J. Sist. dan Inform., vol. 13, no. 2, pp. 36-45, 2019.

[14] M. W. Prihatmono and E. Utami, "Analysis of moving average and holt-winters optimization by using golden section for ritase forecasting," J. Theor. Appl. Inf. Technol., vol. 95, no. 23, pp. 6575-6584, 2017.

[15] Y. Rismawanti and M. Y. Darsyah, "Perbandingan Peramalan Metode Moving Average dan Exponential Smoothing Holt Winter Untuk Menentukan Peramalan Inflasi di Indonesia," Pros. Semin. Nas. Mhs. Unimus, vol. 1, no. January 2018, pp. 330-335, 2020.

[16] R. J. Hyndman and G. Athanasopoulos, Forecasting: Principles and Practice, 2nd Editio. Melbourne, Australia.: OTexts, 2018.

[17] K. Suppalakpanya, R. Nikhom, A. Booranawong, and T. Booranawong,“An Evaluation Of Holt- Winters Methods With Different Initial Trend Values For Forecasting Crude Palm Oil Production And Prices In Thailand," Suranaree J. Sci. Technology, vol. 26, no. 1, pp.13-22, December 2018. 
[18] R. Bertananda and B. D. Setiawan, "Implementasi Performance Improved Holt-Winters Untuk Prediksi Jumlah Keberangkatan Domestik di Bandar Udara Soekarno Hatta," J. Pengemb. Teknol. Inf. dan Ilmu Komput. Univ. Brawijaya, vol. 2, no. 12, pp. 7032 7038, 2018.

[19] Christnatalis, Rinaldi, Andy, B. Seteven, Darmanto, and D. G. Sitorus, "Perbandingan Metode Multiplicative, Additive dan Double Seasonal Holt-Winters untuk Prediksi Penjualan Mobil,” J. Tek. Kesehat. dan Ilmu Sos., vol. 1, no. 1, pp. 89-95, 2019.

\section{(c) (1) (?)}

